Notre Dame Law School

NDLScholarship

Journal Articles

Publications

2006

\title{
Religion and State: Some Main Issues and Sources
}

John M. Finnis

Notre Dame Law School, john.m.finnis.1@nd.edu

Follow this and additional works at: https://scholarship.law.nd.edu/law_faculty_scholarship

Part of the Natural Law Commons, and the Religion Law Commons

\section{Recommended Citation}

John M. Finnis, Religion and State: Some Main Issues and Sources, 51 Am. J. Juris. 107 (2006).

Available at: https://scholarship.law.nd.edu/law_faculty_scholarship/867

This Article is brought to you for free and open access by the Publications at NDLScholarship. It has been accepted for inclusion in Journal Articles by an authorized administrator of NDLScholarship. For more information, please contact lawdr@nd.edu. 


\title{
RELIGION AND STATE: SOME MAIN ISSUES AND SOURCES
}

\author{
JOHN FINNIS
}

These reflections will be philosophical and historical or factual, not theological. They will draw upon and propose considerations which are available in principle to everyone and do not rely on the content of any communication that may have been made to human persons from a transcendent source by means that depart, in some measure, from the patterns that are the subjects of empirical natural and/or social sciences.

This philosophical purpose and method does not, however, have the consequence that many would assume it has, or should have. Many people assume, and some hold with argument and tenacity, that in an enquiry pursued intelligently and without bias any such transcendent source of reality and value is no more than, at most, a bare possibility. They treat as ungrounded and altogether improbable any anticipation or judgment that there has been or may well be some such communication-revelation- from such a source. But the question whether the existence and character of our universe give cogent reason for affirming the existence of such a transcendent explanation is a philosophical question, and one which cannot reasonably and philosophically be given an answer without considering, carefully and with openness, the arguments supporting such an affirmation. They are philosophical arguments, and stronger than many an argument, in many a field of philosophy, that is widely thought philosophically acceptable and warranted. I have rehearsed a number of these arguments for the existence of God in my two main books on political philosophy. ${ }^{1}$

Two of them are taken up by practically every serious-minded person, with degrees of clarity and resolution that differ widely from person to person and culture to culture. The first of these arguments begins by noticing how the

1. John Finnis, Natural Law \& Natural Rights (Oxford: Clarendon Press, 1980), 378-88; Aquinas: Moral, Political and Legal Theory (Oxford, Oxford University Press, 1998), 298-304. In each treatment, the rest of the chapter unfolds some relevant implications which tend to reinforce the bare initial arguments. The remarkable book by Germain Grisez which underpins especially the earlier of these two treatments has been republished with a new title and an introductory exposition of a further argument to God from practical reason's cogency: God? Philosophical Preface to Faith (South Bend, IN: St Augustine's Press, 2004). 
patterns of functioning that everyone observes or infers, and that modern natural sciences successfully describe and explain, always involve a shift, change or movement from one state of affairs (call it P) to another (call it A), such that $\mathrm{A}$ is the actual functioning of the potentiality so to function constituted by or present in $\mathrm{P}$ - a change from potentiality to act which needs explanation and is explained by some further factor, $\mathrm{X}$, acting upon $\mathrm{P}$ and thereby bringing about the change from $P$ to $A$. This line of thought proceeds by noticing that (as natural sciences luxuriantly illustrate) any such $\mathrm{X}$ is itself an actuality (call it $A_{1}$ ) that was shifted from potentiality (call it $P_{1}$ ) by another $\mathrm{X}$ (call it $\mathrm{X}_{1}$ ) and so on. Without presupposing any denial of the possibility that the universe has existed for an infinite length of time (a possibility vigorously and repeatedly defended by Aquinas), this line of thought moves to the conclusion that the universe would be radically under-explained, and indeed could not exist, unless there is some quite different sort of explanatory factor, some sort of reality which can contribute to the explanation of every $\mathrm{X}$ (and thus every A and the whole universe of As) but can do so without changing or ever needing to change from potentiality to act-a sheer act(uality), free from any mere potentiality, and capable of bringing into actuality and existence anything and everything which, but for that, would and could have had no actuality at all.

Such a creative bringing of states of affairs into being also makes it possible to point to the explanation sought in the second line of thought which is pursued by any serious-minded person. This line of thought seeks to explain the mathematically expressible orderliness of things, the orderliness and directionality of states of affairs (events and things) which (not without fortuity and disorderliness) is so thoroughly characteristic of the world we know. And the explanation sought and proposed shows that such directionality is to be understood as a directedness resultant from something not altogether unlike our intentionally putting into effect an intelligible plan of action. This second line of thought enhances the first by showing the need to think of the transcendent pure act(uality) as intelligent and free, albeit in a manner altogether surpassing our intelligence and freedom. Thus the two lines of thought converge in the judgment that there exists a reality such as is everywhere referred to by the name "God."

The second line of thought has a further consequence. Since we have intelligence, including the capacity both to project (express) meaning and to share it, and some freedom to choose between alternatives understood by us as more or less desirable, it is reasonable to hypothesize and anticipate that there might at some time be some projection, to us, of meaning and shareable purpose, from the infinitely greater intelligence and purposiveness needed to explain the existence of our universe including our own mysterious but 
commonplace sharing with each other of meaning and intentions. Philosophy here bids us cast about for historical evidence of such transcendent revelation, if any there be. In doing so, philosophy does not yet consign us to theology. The judgment that certain events are best understood as instances of a transcendently revelatory communication is one that builds on the philosophically (and common-sensically) grounded affirmation of the existence of a creator, and on historically warranted affirmations that certain words were spoken and deeds done with certain intentions. The judgment draws also on the complex range of presuppositions and insights that shape judgments about personal credibility. And it also draws (or needs to be in a position draw) on an assessment of the array of theological arguments which show that the contents of the revelation or teachings of its messengers at no point contradict reason. But none of this amounts either to making an act of faith, that is of submitting one's mind and will to the revealing God, ${ }^{2}$ or to doing or endorsing theology, the discipline that takes as axiomatic the propositional content of divine revelation.

The philosophical argument to God does, however, warrant and include judgments that are theological in a broader sense. What is traditionally called natural theology is that part of philosophy which, while remaining strictly and integrally philosophical, speaks of such things as God's existence and nature as intelligent, free and so forth. Similarly, despite what many say, a historical judgment of the kind hypothesized above would not cease to be authentically historical merely because it affirmed that the most reasonable explanation of certain extraordinary events is their being acts of divine revelation.

Moreover, there can be (and is) a mutual support, and in that sense interdependence, between the philosophical and the historical, each capable of giving the other a degree of clarity and certainty not available to it in isolation

2. On faith and its inter-relationship with the rational judgment that God exists and that a specific set of events communicates the divine purpose of creating (and, as it may be, of restoring), see Germain Grisez, The Way of the Lord Jesus, vol. 2, Living a Christian Life (Quincy, IL: Franciscan Press, 1993), ch. 1. I differ from this rich and penetrating treatment only in so far as sec. C.3 (pp. 13-14), says without qualification (such as Grisez might well wish to make) that Islam is one of the three "biblical religions" which offer a sound account of God and human persons, an account which is true humanism, forestalls modern thought's problem with free choice and objectivity, and responds to human hopes and expectations. Islam appears to me to offer unsound accounts of God, and human destiny, and to be anti-humanist and unclear about free will. Above all, Islam's partial endorsement of the Bible does not at all reinforce the grounds for accepting the Bible, and where Mohammed departs from the biblical revelation and proposes an alternative account of God and salvation his teaching lacks philosophical, moral or historical merit insofar as it differs substantially from the Bible read as it is read in the ecclesial body whose founding and teaching is witnessed to in the New Testament. 
from the other. John Henry Newman's profound discussions of antecedent probabilities, from his 12th Oxford University Sermon (1839), through his $A n$ Essay on the Development of Christian Doctrine (1845) to his A Grammar of Assent (1870), bear in good measure on this network, this virtuous upward spiral, of mutually supporting considerations, presumptions and grounds for accepting hypotheses that go, in varying ways, beyond the warrant of the simply perceptible towards - go, indeed, all the way to-responsible, critical and warranted affirmation or confirmation not only of the transcendent and divine (affirmations of which are primarily philosophical) but also of concrete revelatory divine intervention, more or less praeternatural, in human affairs (affirmations of which are primarily historical). It is such a network of convergent considerations, starting with the antecedent reasonableness of anticipating some communication between the intelligent Creator and the other intelligences in the created universe (us), that (as Newman shows) ${ }^{3}$ subverts David Hume's a priori argument that the probability that an apparent miracle is miraculous must always be lower than the probability that the laws of nature prevail without exception. Given the certain dependence of the laws of nature on the creative intelligence and will of an actuality not limited by any mere potentiality, it is neither contrary to nor beyond reason to expect that the course of human history might well include events, of communicative significance, going beyond or contrary to the laws that generally structure affairs. Nor need it be unreasonable to judge that such a communicative event did actually or very probably occur at such and such a time and place.

In making a responsible judgment of this kind, one will meet with another kind or instance of such rationally reinforcing interdependence: that between moral character (and the moral judgments which assess it) and the credibility of witnesses and prophets (and the factual/historical judgments which assess it). To the question whether a prophet asserting divine revelatory words or deeds is to be believed, one should indeed bring questions both about philosophical cogency and about historical evidence, but also questions about the moral creditworthiness both of the evidentiary witnesses and, perhaps even more importantly, of the supposed prophetic witness to divine communicative words or deeds of revelation. A self-styled prophet, however impressive are certain aspects of his theological teaching, undermines his credibility whenever he shows himself to be morally flawed, especially if his claim is to be the primary bearer of a new revelation and founder of new institutions or

3. An Essay in Aid of a Grammar of Assent, ed. Ian Ker, (Oxford: Oxford University Press, 1985 [1870]), 199. I have tried to put this in the wider frame of rationality norms in "Historical Consciousness" and Theological Foundations, Etienne Gilson Series no. 14 (Toronto: Pontifical Institute of Mediaeval Studies, 1992), 20-21. 
arrangements for carrying it forward in perpetuity, and especially if his moral flaws give reason to judge his supposed messages self-serving-as, for example, when he says that the God whose messenger he is has dispensed him from certain sexual restrictions, or has authorized him and his followers to require of anyone else adoption of their message on pain of death or servitude. ${ }^{4}$ The same goes for the character and methods, morally assessed, of those who hold themselves out as witnesses to the principal prophet or founder. Apostles who are willing to kill or otherwise coerce, or to offer carnally seductive incentives ("the women that thy right hand possesses"), in support of their testimony and of the Prophet's message, should be contrasted with apostles who make no such threats but are willing to be killed rather than renounce their testimony or message at the demand of ruthless persons. The contrast gains in significance if it corresponds to differences in the contents of the respective revelations which these differing sets of witnesses preach. Such moral contrasts have great epistemic relevance. They bear directly on what is the most reasonable answer to the questions both about evidence and about substantive acceptability that are decisive for the primarily historical judgment that such-and-such is or was, or is or was not, an instance of divine revelation. And such moral contrasts also bear directly on any consequent moral decision (choice) to take the revealed message as a guide to one's actions.

So it was not merely a matter of taxonomy, or a mere academic concern privileging method over substance, that led me to begin these reflections on "religion and state" by pointing out the overlap between philosophy and theology, and between reason and faith. Any discussion of religion and state derails from the outset if it presumes that, as Brian Leiter puts it, "religion is contrasted with reason"s-a theory for which Leiter, if he felt inclined, might summon as a supporting witness the first definition of "religion" in Webster's New Universal Unabridged Dictionary (New York 1992). And the discussion equally derails if it presumes that no religion's claims about God and man, world and society are reasonable, or that no religion's claims are even discussable within the domain of public reason, that is, of the discourse that one should find in universities, schools, and legislative and other political assemblies, including discourse about what laws and public policies to adopt. The discussion derails, again, if it presumes that the philosophically neutral,

4. See also Aquinas, Summa contra Gentiles I, c. 6.

5. "Religious Reasons and State Power" (26 July 2006), http://leiterlawschool.typepad .com/leiter/2006/week30/index.html. 
default, baseline or otherwise presumptively appropriate framework or basis for the discussion of religion and state is that no religious claims add anything - whether content, certitude, or probability - to what is established in moral or political philosophy, or in natural or social science or social theory.

It derails, too, if it holds or presumes that religion's status is nothing more than one way of exercising the "right" proclaimed as fundamental and "at the heart of liberty," in Planned Parenthood v Casey (1992): "to define one's own concept of existence, of meaning, of the universe, and of the mystery of human life." Or again if, as Ronald Dworkin says, the basis of the First Amendment's guarantee of religious freedom is simply that "no one can regard himself as a free and equal member of an organized venture that claims authority to decide for him what he thinks self-respect requires him to decide for himself." These celebrations of the right to "decide for oneself" and "define one's own concept" trade, as we shall see, on an important truth. But they abandon reason when they assert that the relevant intelligible and basic good in issue is not the good of aligning oneself with a transcendent intelligence and will whose activity makes possible one's own intellect and will, nor even the good of discovering the truth about some meaningful and weighty questions, but rather the good of self-determination or of self-respect. For these are no true goods unless the goods around which one determines oneself deserve the respect due to what is true, rather than self-interested make-believe.

In line with one reading of some remarks of mine in Natural Law and Natural Rights, ${ }^{8}$ Joseph Boyle's important paper on "The Place of Religion in the Practical Reasoning of Individuals and Groups" (1998) argues that even "one who is not motivated by religious conviction" can be aware of the reason to seek-can see the point of seeking-harmony with the divine," harmony that is Boyle's working definition, rather like Cicero's, of what religion is about. I agree with this insofar as it points out that the line between ability and inability to recognize the good of religion does not track the line

6. 505 U.S. 833 at 851 . Celebrated in the Philosophers' Brief of Ronald Dworkin, John Rawls and others in Washington v. Glucksberg, 521 U.S. 702 and Vacco v Quill, 521 U.S. 793 (1997): Dworkin et al., “Assisted Suicide: The Philosophers' Brief," New York Review of Books 44 (1997) 41.

7. Ronald Dworkin, Justice in Robes (Cambridge, MA, Harvard University Press, 2006), 134. See also Ronald Dworkin, Is Democracy Possible Here? Principles for a New Political Debate (Princeton, NJ: Princeton University Press, 2006), 60-62.

8. See Natural Law and Natural Rights, 90; cf. 410.

9. Boyle has in mind here, primarily, someone who has no religious conviction and perhaps instead the conviction that all religious claims are false and there is no transcendent source of being and meaning.

10. American Journal of Jurisprudence 43 (1998) 1-24, 10. 
between a sound theistic belief and confused alternatives. But there are nonbelievers and non-believers, and radically different senses of "seeing the point" of some logically possible object of choice. One who thinks "If there were a divine source of reality and meaning, being in harmony with it would be a basic form of human good, but there is no reason to believe that there is any such source" may well, and reasonably, conclude that religion is not a basic good and indeed no good at all save as a kind-a rather imperfect, distorted and distorting kind-of self-determination, of exercise of a Caseystyle defining of one's own concepts, perhaps to fit some of one's raw desires and aversions. For all who hold this sort of view of what reason-if you like, philosophy — has to say about religious claims, the place of religion in schemes of constitutional or human rights is only historically grounded. They may have no intent to set the state or its government and law against religion, still less to scorn the personal and social benefits religious belief may sometimes (perhaps often) be instrumental in yielding; but, for them, religion's constitutional status and immunities are as instances (and scarcely exemplary) of the only really basic human good, the only intrinsically worthwhile end, at stake: settling for oneself one's stance in the world. ${ }^{11}$ Like Boyle, I think it is important not to conduct one's reflections about religion and state on this false premise. The importance of not doing so is all the greater because selfdetermination itself is now widely regarded, not least among our constitutional lawyers, as a form, not so much of shaping up as best one can to what one judges in conscience to be reason's demands on one, but rather as the bundling of one's strong desires, one's "deep concerns," most considerable when most passionate. In such a line of thought (formalized within a year or two of Casey), ${ }^{12}$ religion is doubly discredited, first by the casual assumption that it

11. Boyle's assumption, which his article intends to test (and confirm), is "that the good of religion has rational appeal prior to such articulate beliefs about God [as that God is a personal being with whom cooperation is possible]." Ibid., 15n. That assumption may in the abstract, and in certain contexts, be sound while being unsound in a context where an understanding of the personal God of Abraham and Isaac and Jesus has been made available (not altogether inadequately) to virtually everyone. One who rejects that understanding of God is poised to reject the thesis that it is good to consider oneself in harmony, through awe and worship, with a being one has imagined or postulated. (And so a good many people object to, or are puzzled by, the inclusion of religion in the list of basic goods in Natural Law and Natural Rights.) Just as "religion presupposes some views about the divine and about the rest of reality" (Boyle, op. cit., 5), so too acceptance that religion has a distinct intelligible point presupposes the view that its views about the divine are not simply false (and demeaning).

12. Christopher L. Eisgruber and Lawrence G. Sager, "The Vulnerability of Consciences: The Constitutional Basis for Protecting Religious Conduct" University of Chicago Law Review 61 (1994) 1245-1315, 1266. (The title can give a mistaken impression of the authors' central thesis; they deny [pp. 1263, 1268-70] that conscience as the rational faculty of practical 
is outside the domain of reason, and then by hostility to its unwelcome critiques of and constraints upon "deep" desires. Its place in the constitution can be accepted only grudgingly as a historical relic and a monument to the threat that religions characteristically have posed to each other as well as to everyone's "conscience" (reconceptualised as the articulation of their "deep concerns").

Our reflections will go soundly if they treat affirming God as within the full reach of the critically disciplined reasoning we call philosophy, and treat affirming the political common good (including politically acknowledged human rights) as within the full reach of critically disciplined practical reason at its highest: political philosophy. Each of these affirmations-of God and of a true public interest or common good-confronts openly skeptical denials, and the fair-weather friendship of fideistic or merely conventional concurrence, and the masked skepticism communicated by concepts such as Rawls's "burden of judgment" and "fact of pluralism." The "inevitably" controverted character of each of the two affirmations or affirmation-clusters only challenges us to think more resolutely, and in no way robs them of their privileged status as, in each case, the truth of the matter (or a worthwhile part of it). It is a status that each is entitled to, by its rational soundness.

\section{III}

Before we turn to consider how all this bears on real-life political communities, we might reflect that claims about divine revelation do not rise to the level of the philosophically considerable unless the group which advances them is willing to defend the historical assertions which are the core (albeit not the whole) of its claims. Beginning about 120 years after John Henry Newman's conversion, the Church which he joined and adorned experienced a severe and still ongoing loss of faith among its members and of political and other influence in many parts of the world where it had been well established. Though the main causes of this are complex, and that Church's demanding moral teaching is prominent among them, they centre, in my estimation, on the loss of confidence in the truth of those Gospel teachings that warn insistently of the utterly grave and unending consequences of one's seriously wrongful and unrepented choices. And in turn this loss of confidence derives, in some large measure, I believe, from the weakening of belief that in the four Gospels and the Acts of the Apostles we have, albeit in

judgment has any more claim than religion to constitutional privilege or even protection; the proper object of constitutional protection is any "deep concern," any and all "deeply" motivated and self-shaping attitudes and behavior, which whether or not religious or even conscientious are all alike entitled to "equal regard.") 
theologically inflected form, a truthful and sober account of things actually said and done by a man whose divine authority and, indeed, nature was attested not only by his moral authenticity and virtue but also by his transcendence to the laws of time and nature. And this weakening of belief in the historicity of the testimony of the apostles and their confidantes has among its primary causes the adoption by many of that Church's scripture scholars, and accordingly by those whom they teach and advise, of a philosophically unsound presumption against that transcendence to laws of nature-against the miraculous.

The Gospels could be credible witnesses to everything they report even if they were written after $A D$ 70. But scholars poison the root of the tree if a main reason for their concluding that a Gospel dates from after AD 70 is that otherwise its foretelling of the fall of Jerusalem ${ }^{13}$ would outrun human knowledge and ignorance of the future. ${ }^{14}$ For then the reports that Jesus foretold those events become historically discreditable, and efforts to save them from the status of falsehoods, by denying that they were intended to assert the happening or content of any actual event or statement, ripple out from these passages and change - infect - the reading of all other parts of the narrative in the Gospels (and Acts). All parts become not accounts or reports but "stories," in the equivocal terminology of the modern preacher. Of course every historical inquiry should start with a definite presumption that the events under investigation transpired in accordance with the laws of nature. But that presumption can rationally, and should, be qualified and (in due measure, and with due caution) set aside, once a convergent set of considerations (bearing on those events' antecedents, concomitants, content and sequels) make it probable that the events were part of a divine communicative intervention. For once that becomes probable, the philosophically warranted, indeed compelling, principles of methodological consistency demand that the investigation's initial presumptions, including the presumption against miracles, should be revised and indeed abandoned to the extent that the whole range of grounds for

13. Matthew 23: 37-39; 24: 1-2; Mark 13: 1-2; Luke 13:34-35; 19:41-44; 21: 5-6, 21-24.

14. Of course, just as scholars such as John A.T. Robinson, Redating the New Testament (London: SCM Press, 1976) and John Wenham, Redating Matthew, Mark \& Luke (London: Hodder \& Stoughton, 1991) argue from the silence of the New Testament about the circumstances and sequelae of the fall of Jerusalem in $\mathrm{AD} 70$ to the conclusion that the Gospels and Acts ante-date that event, so more conventional recent scholars may argue that features of and/or elements in the Gospels quite distinct from the prophecies of the fall of Jerusalem attributed to Jesus suggest a post-70 origin for Matthew and Luke if not also Mark. The point I am making does not touch the latter line of argument (though I do not find it persuasive), but concerns those who overtly or covertly assume that the prophecies are ex eventu-made up after the event-and employ that assumption in the approach to the dating and historicity of the Gospels. 
judgment makes appropriate. If Jesus of Nazareth was in any way divine, or even an authentic witness of the divine, he could speak with miraculous foreknowledge about the future of Jerusalem. So if he presumably didn't, he presumably couldn't, and so presumably wasn't divine. (The other category, "merely human messenger of the divine," is inapplicable to this man, because, if we know anything significant about what he said and did, we know that he claimed to be divine.) Of course, many scholars (and bishops who follow them) are inconsistent and inattentive to implications. They don't, I think, mean to run the theorem as I just did. But, like it or not, it does run that way, poison (to the proclamation of revelation) from root to leaf. A religion that remained at peace with such incoherence would drop below the horizon of philosophy, and could not claim the adherence of any earnestly enquiring mind. It would fail to live up to the demands of public reason. ${ }^{15}$

\section{IV}

What then does a sound philosophy of politics have to say about political communities in which there is no consensus about this world's dependence upon a divine creator, and still less consensus about whether and if so where and how there has been any communication to us from any such creator? Even assuming (as we should) that neither atheism nor agnosticism is the rational default position for political philosophy, what is to be said, within political philosophy, about the place of religion in political communities very many of whose members treat atheism or agnosticism as their default position in both their daily lives and in their political deliberations?

These questions can be answered well by considering first a society in which adherents of sound philosophy, both political/moral and religious, have procedurally fair and constitutional authority to settle the laws and their execution. How should the laws and public policies of such a state bear on religion? Answering that first form of the question will provide a sound basis for answering the question in its second form, today more engaging but inherently subordinate, about a society which is deeply pluralist in religious beliefs, if not also about political and individual morality. My discussion focuses on the first and basic form of the question, though some of the implications for more deeply divided societies should become apparent.

15. On public reason, coherently and critically understood, see Finnis, "Abortion, Natural Law and Public Reason," in Natural Law and Public Reason ed. Robert P. George and Christopher Wolfe (Washington DC: Georgetown University Press, 2000), 71-105; "Natural Law and the Ethics of Discourse," The American Journal of Jurisprudence 43 (1999) 53-73. 


\section{V}

Political philosophy draws on experience, including experience which is only in a loose sense "available to all" and is better called historical. And so it is not impossible, and indeed is positively fitting, to consider as essentially political-philosophical (and not merely positive law) that legal position on religion and state which is articulated in (1) the United States Constitution's First Amendment protection of "the free exercise of religion," and in (2) the European Convention on Human Rights art. 9.1's guarantee that

Everyone has the right to freedom of thought, conscience and religion; this right includes freedom to change his religion or belief, and freedom, either alone or in community with others and in public or private, to manifest his religion or belief, in worship, teaching, practice and observance

(subject to the considerations of public order spelled out by art. 9.2), and in (3) the Second Vatican Council's Declaration (Dignitatis Humanae) on Religious Liberty. The Council's identification of the right to religious liberty closely tracks the European Convention's. Much more clearly than the Convention, however, it identifies the right not as a Hohfeldian "liberty-right" but as an immunity, of individuals and groups, from coercion-including coercion by private individuals or groups-in respect of religious belief, and all those expressions of religious belief, or other acts of putting one's religious belief into practice, that are compatible with laws motivated exclusively by concern to uphold just public order, that is (as sec. 7 of Dignitatis Humanae spells out) the rights of others, public peace and public morality.

To show that this immunity from coercion is a natural law right, violation of which is "intrinsically unjust," the Council puts forward two lines of argument. The first and much more extensively expounded has as its major premise: "everyone has a moral obligation to seek the truth about religious matters, and adhere to whatever truth one finds." Then its minor premise is: "one cannot live up to that obligation in a manner appropriate to one's nature as a rational and responsible person unless one has immunity from external coercion as well as psychological freedom." The minor premise, as is usual in practical syllogisms, is essentially one of fact (albeit not brute fact)-the fact referred to by the word "cannot"-and this fact is what the Council is

16. Acta Synodalia Sacrosancti Concilii Oecumenici Vaticani II, vol. IV, pars VI (Vatican City: Typis Polyglottis Vaticanis 1978), 761 (reply to modus 3 to sec. 10). But should it not be admitted that this is a weak form of intrinsece malum (intrinsic moral wrong), since the identification of the (morally excluded) object of choice involves a reference to (further) intentions and to circumstances-namely, that the proposed coercion is not intended (or needed) for the sake of preserving the rights of others, public peace or public morality? 
pointing to when in sec. 9 it says that "the exigencies of the dignity of the human person have become more fully known to human reason through centuries of experience." This is one of the kinds of historical experience that political philosophy needs to draw upon, and can draw upon without ceasing to be philosophical.

It might be objected that coercion in religious matters does work. True, in those immediately subjected to it may induce little or nothing more than a spiritually worthless conformity to the coercing authority's demands for specified conduct or abstentions. But, so the objection goes, experience ${ }^{17}$ shows that the children and descendants of the coerced may well live an authentic religious faith and practice in the form, or with the restrictions, coercively imposed upon their parents or forebears. To which the principal reply is that a good end, or end-state, cannot justify means which are wrong intrinsically, that is by reason of their object, that is, their proximate intention, not by reason of their further consequences. Insofar as coercion applied to $P_{1}$ has as its object a change of mind by $P_{1}$ about religious matters, it will be intrinsically wrong even if it has the consequence that $P_{2}$ and $P_{3}$ later adopt true religious beliefs by an authentic process of enquiry and reflection. That reply is not available where the object of the coercion is to stop conduct which is a violation of the rights of others or of public peace or public morality. Nor is it available where the intention in coercing $P_{1}$ is not to change $P_{1}$ 's religious beliefs but $P_{2}$ 's and $P_{3}$ 's. Here the reply will have to observe that the final balance-sheet of consequences of those uses of coercion (just or unjust) has not yet been filled out, even from the viewpoint of the persecutors. And it will give full scope to what experience has taught about coercion's effects upon people's conceptions or misconceptions of the transcendent creator, effects alluded to by Pope Benedict XVI in his lecture on 12 September 2006 in the University of Regensburg:

The emperor [Manuel II Paleologus in his debate c. 1391 with a learned Moslem], after having expressed himself so forcefully, ${ }^{18}$ goes on to explain in detail the reasons why spreading the faith through violence is something unreasonable. Violence is incompatible with the nature of God and the nature

17. Consider the realm of Islam, or the near extinction of England's once vibrant Catholicism over the 250 years following Queen Elizabeth's accession to the throne in 1558 , or the transformation of Mormon beliefs about polygamy by remorseless use of Federal coercive power between the Morrill Act of 1862 and the Mormon Church's capitulation in September 1890 . The issue here is whether these repressions were effective, not whether they were justified.

18. This alludes to a remark by the Emperor, just quoted by the Pope, which expresses "forcefully" an estimation of how Islam stands to biblical revelation and faith rather similar to that proposed in supra, note 2 and in the passage in Aquinas, $S c G$ cited in supra, note 4. 
of the soul. "...not acting reasonably ... is contrary to God's nature. Faith is born of the soul, not the body. Whoever would lead someone to faith needs the ability to speak well and to reason properly, without violence and threats... To convince a reasonable soul, one does not need a strong arm, or weapons of any kind, or any other means of threatening a person with death...."

The decisive statement in this argument against violent conversion is this: not to act in accordance with reason is contrary to God's nature.

So, as the Regensburg lecture suggests, coercion for the sake of religion has the very bad consequence of ruining people's understanding of that object (subject) of inquiry which it is most important not to misunderstand. If it be objected that the violence and unreasonableness are contrary not to the nature of God but to the human good of religion, the proper reply is that they are contrary to both. Religion as a human good is the condition of being in harmony with the transcendent providential explanatory cause of the created world, and what it is to be in that harmony cannot be rightly understood or postulated without some conception of the nature (wise? arbitrarily violent?) of that transcendent and personal cause. So it was with good reason that the Council began its argument for religious liberty (as an entailment of the human good of religion) with some summary reminders of the divine wisdom and love (that is, will to favour true human good, precisely for its-human persons'-objective goodness and worth). ${ }^{19}$

To support its case that coercion of religious belief, expression, and religiously motivated conduct is "intrinsically unjust", the Council adds a second, much less extensively articulated argument:

The religious acts whereby people, by their personal judgments, privately or publicly direct their lives to God transcend by their very nature the order of earthly and temporal affairs. The civil power therefore, whose proper responsibility is to attend to the temporal common good, ought indeed to recognize and favor the religious life of the citizenry, but must be said to exceed its limits if it presume to direct or inhibit religious acts. ${ }^{20}$

19. See Dignitatis Humanae, 3.1, and note the parallel use of suaviter ("without force") in 1.3 and 3.1.

20. Standard English translations such as that on the Vatican website are particularly poor. The text (which presents no genuine problems to translators): "Praeterea actus religiosi, quibus homines privatim et publice sese ad Deum ex animi sententia ordinant, natura sua terrestrem et temporalem rerum ordinem transcendunt. Potestas igitur civilis, cuius finis proprius est bonum commune temporale curare, religiosam quidem civium vitam agnoscere eique favere debet, sed limites suos excedere dicenda est, si actus religiosos dirigere vel impedire praesumat." 
The repeated and key word here is "temporal," which draws in the whole tradition of thought that I summed up in my book on Aquinas's political theory like this (I abbreviate) $:^{21}$

[Aquinas judged that] God's self-communication included propositions about complete human fulfilment in eternal life; and about the community which Jesus established both to transmit that divine promise of eternal life and to help people make themselves, by free choices, ready for that life (and indeed somehow already participants in it). ....

So human associations are henceforth of two fundamentally distinct types. On the one side is the 'temporal' or 'secular': the names connote a time-bound association and role; Aquinas uses them, in relevant contexts, as synonymous with 'worldly' \{mundanus \} and 'civil' or 'political' \{civilis\}. The contrast is with a 'spiritual' association organised, by divine inspiration, towards eternal participation (albeit in a somehow bodily way) in the non-bodily (spiritual, mind-like) life of God. ${ }^{22}$ The spiritual association par excellence is a church (in Latin ecclesia, transliterating the Greek synonym for Latin's congregatio); paradigmatically it is the society of 'the faithful' \{congregatio fidelium\}...

The sole organising purpose of the Catholic Church is that there be beatitudo perfecta in eternal life for, so far as possible, all human persons, of every family, association, state, and people. It has no 'secular' purposes. Responsibility for human affairs is thus divided between, on the one side, the Church and, on the other side, secular societies, most notably states and families. ....

The rationale of secular authority is, for a parent, to manage a household in which the children are nurtured and protected, fairly dealt with, and educated by instruction and discipline, in the hope that they will gain eternal life; for the lawmakers and other rulers of a state, the secular mission to secure peace and justice within its territory. ${ }^{23}$

Aquinas himself is very clear (at the level of principle) that the coercive jurisdiction of temporal political authority extends only to external and interpersonal acts-acts which implicate the community's peace and justice. ${ }^{24}$ Though external acts are of course, as Aquinas explains better than anyone, behavior shaped by and putting into action the internal acts which we call intending and choosing, Aquinas is firm in his assertion, if not altogether clear in his explanation, of several points. First: internal acts as such are inaccessible to human authorities; ${ }^{25}$ main texts of his on this point were in the footnotes to Dignitatis Humanae's first argument for the immunity of religious

21. Finnis, Aquinas, 321-2.

22. See e.g. Summa Theologiae, II-II q. 183 a. 1c; a.2 ad 3.

23. So the "justice by which human society is governed in line with secular political good \{ad bonum civile\} can be sufficiently attained through the principles of natural right available to everyone \{principia iuris naturalis homini indita\}": Aquinas, de Veritate, q. 12 a. 3 ad 11.

24. Aquinas, 222-245.

25. Aquinas, 241. 
acts, in all drafts including the last. ${ }^{26}$ Second: "personal" acts of selfdisposition such as whether and whom to marry, or whether to make a religious vow, ${ }^{27}$ are quite beyond the jurisdiction of state government and law. Third, things like "matters of faith and divine worship, and similar matters," even though everyone ought to do them in the same way and everyone benefits from their being done, nevertheless "do not consist in community and pertain to each individual person in himself ad unum aliquem pertinet secundum seipsum\}."28 Aquinas's philosophical arguments for these positions are the arguments deployed in Dignitatis Humanae-arguments from the essential interiority and inaccessibility of such acts, and from the limitation of the state's coercive jurisdiction to matters that are public, not purely private- though Aquinas supplements his arguments by appeal to the essential equality of persons, and Dignitatis Humanae raises the whole set of arguments to a new plane by making primary one's serious duty to pursue the truth about ultimates and to shape one's life in line with what one judges one has discovered about them, a duty that is only fulfilled if it is pursued with an authenticity which coercion and "psychological pressure" prejudice, corrupt and tend to nullify.

Adding clarity and certitude to the philosophical arguments both of Aquinas and the Council are the Declaration's theses of (as it asserts) divine revelation and divinely guided ecclesiastical tradition: the division of jurisdiction implicit in "Render to Caesar the things that are Caesar's, and to God the things that are God's," and from the earliest apostolic times onward the unbroken refusal to countenance any attempt to coerce someone to embrace the Christian faith against his or her own will..$^{29}$ Indeed, all the elements of the Council's declaration of a natural, human right to religious liberty are taken from authorities as traditional as Aquinas, and none of the principles defended by Aquinas is contradicted. As the drafting committee advised the Council fathers orally and in writing in the two days before the final vote adopting Dignitatis Humanae, the old thought that error has no rights remains unchallenged. Understanding "liberty" in its strict (Hohfeldian) sense-

26. Attached to the fourth sentence of para. 3 of no. 3 ("For the exercise of religion, by its very essence, consists primarily in voluntary and free internal acts by which man directly orders himself to God: acts of this kind cannot be commanded or prohibited by merely human authority.") was the footnote: "Cf. S. Thomas, ST I-II q. 91 a. 4c: 'Man can make laws about those matters about which he can judge. But there can be no judgment of man about interior acts which are hidden, but only about exterior acts which are manifest'; cf. II-II q. 104 a. 5c: 'In matters which pertain to the interior movement of the will, man is not bound to obey man but only God.' ..."

27. Aquinas, 239-41.

28. Summa contra Gentiles, IIl c. $80 \mathrm{nn} .14,15$; Aquinas, 226. 253-4.

29. Dignitatis Humanae, 10. 
absence of duty - there is no moral liberty to proclaim a false religion. ${ }^{30} \mathrm{But}$ there is the human right (Hohfeldian claim-right) to be immune from coercion by individuals, groups, governments or laws, in one's religious or religiously motivated acts, provided they are in line with public order; and the acts thus immune include adhering to and proclaiming a religion which one believes to be true but is in fact false. Taking common good in its widest extension, it is for the common good of the members of a political community that they find the truth about divine creation and redemption, live in accordance with that truth, and so enter and remain for ever in the altogether fulfilling fellowship of the divine family extending from this world into eternity. But the state is responsible only for temporal common good, and correspondingly the coercive jurisdiction of state government and law has as its defining objective not the widest common good which might include salvation itself, but what the Council calls a (or the) "basic component of the common good," namely public order. $^{31}$ The entire shift away from mediaeval and early modern, ecclesiastically sponsored practices of state coercion of, or arising out of, religious beliefs and acts is carried out by a shifted emphasis among, a clarifying reordering of, a set of truly perennial principles.

\section{VI}

Philosophically assessed, without the philosophically unsound presupposition of atheism or agnosticism about creation and revelation, the natural law thesis articulated in Dignitatis Humanae, like its positive law antecedents in the U.S. Constitution and the European Convention on Human Rights, constitutes a sound and true civilizational core. It is a centering pole between unsound secularist and theocratic alternatives.

Secularists, presuming or asserting that religion cannot be grounded in rational enquiry that issues in true judgments, may nonetheless remain within the tradition of their society and admit religious concerns and acts among the "grand diversity of relationships, affiliations, activities, and passions that share a constitutional presumption of legitimacy" because in them (as Eisgruber and Sager put it) the members of "a modern, pluralistic society ... find their identities, shape their values, and live the most valuable moments of their lives." 32 Religious acts, they concede, have the same dignity and constitutional status as the "relationships, affiliations, activities and passions" under

30. Acta Synodalia Sacrosancti Concilii Oecumenici Vaticani II vol. IV pars VI (Vatican City: Typis Polyglottis Vaticanis, 1978), 720-722, 725 (response to "general modus" no. 2, repeated by cross- reference twenty times in subsequent responses to modi).

31. Dignitatis Humanae, 7.

32. Eisgruber and Sager, "The Vulnerability of Consciences," 1266. 
discussion. Eisgruber and Sager's article does not say how far this wider category extends, but it seems they would include (and not merely marginally) the activities in issue in in Bowers $v$ Hardwick ${ }^{33}$ and Lawrence v Texas, ${ }^{34}$ and likewise those in Roe $v$ Wade ${ }^{35}$ and Planned Parenthood $v$ Casey, ${ }^{36}$ activities which often, it is not unreasonable to suppose, express not so much conscience or any other concern for truth as very strong (deep) emotional desires of the kind that are so often the subject of belated rational regret. ${ }^{37}$ Secularists differently placed have often drawn conclusions less favorable to constitutional respect for or even tolerance of religion, as we have seen in many places over many decades of the twentieth century.

And at the other end of the spectrum at whose center stands Dignitatis Humanae are the theocracies. These are exemplified in the early modern world by Elizabethan and Jacobean England-in which citizens are directed to perform the religious acts of a worshipping community that is treated as coterminous with the state and whose leaders and ceremonies are specified directly by the state's government. Today they are exemplified by the two main Islamic forms, Sunni, in which like Anglican England the state appoints religious leaders, and Shi'ite, in which (like Puritan England and Calvinist Geneva) the political community and all its members are subject to the coercive control and jurisdiction of the religion's leaders. Radicalized, in ways that have not convincingly been shown to be unfaithful to the core texts or traditions of Islam's purported divine communication, these two forms can together be called Islamism, which in its outward looking aspect often describes itself as Jihadism, and has a variety of forms which it is not necessary here to itemize.

33. 478 U.S. 186 (1986) (casual homosexual sodomy)

34. 539 U.S. 558 (2003) (casual homosexual sodomy)

35. 410 U.S. 113 (1973) (elective abortion)

36. 505 U.S. 833 (1992) (elective and lifestyle abortions)

37. True, sometimes acts of the kinds in question (acts of non-marital intimacy, elective abortions) are sought for conscience's sake, and religious acts are sometimes or even rather often performed for reasons other than conscience. But Eisgruber and Sager's argument looks only to the "deepness" (and in that equivocal sense authenticity) of the concern that underlies the protected class of activities, and sets aside any requirement (whether at the level of explanatory principle or of constitutional test) that the concern and self-determination have the responsibility (ultimately to truth and thereby also to other persons) and alertness to intrinsic worth implicit in conscience and religion.

Similarly, Dworkin's argument in Is Democracy Possible Here?, 60-62, while it speaks of "a general right to decide matters of fundamental ethical importance for oneself"-and illustrates this with the examples of having an abortion, practicing homosexuality, engaging in stem-cell research, and committing suicide "when terminally ill and in pain"-dilutes any implicit reference to truth and responsibility by speaking constantly of "decision" and "choice with respect to ethical issues:" "freedom of choice in all ethical matters" (p. 62). 
It is worth adding one further factual observation about the present disposition or alignment of civilizational blocs, groupings or "forces." Just as the Catholic Church's doctrine of religious liberty is pointedly aimed, in one direction against secularist (say American) devaluation of the earnest search for truth about religion and life and secularist (say Communist) repression of religion, and in the other direction against anti-philosophical and anti-Christian (not to mention anti-Semitic) theocratism, so too that Church's members, in their political and day-to-day involvement with issues very fundamental to the legal protection of life and freedom, find themselves allied, variously, with each of those ends of the spectrum against the other. That is part of what it is to be central to civilization.

\section{VII}

So state governments and legal systems have a negative duty: not to coerce religious acts unless these threaten the rights of others, public peace or public morality. Have they other negative duties, perhaps the duty not to discriminate between adherents of one religion and adherents of another? And have they any positive duties, say (as we have seen Dignitatis Humanae saying) to encourage the religious activities of citizens, or again to perform what the Council calls ${ }^{38}$ "the moral duty of men and societies toward the true religion and toward the one Church of Christ"?

Joseph Boyle gives the following positive formulation to the negative duty, and to the Council's arguments for it from authenticity and jurisdiction. His formulation is one that seems to enhance the duty's negative implications by cutting off any favor for a particular religion, any disfavor for a specific religion, and any favor for religion over irreligion or for irreligion over religion:

Political society is morally obliged to create the social space for people to fulfil their obligation to seek the truth in religious matters and live accordingly. It cannot do this if political life is conducted as if a certain outcome of this inquiry-whether a particular kind of belief or nonbelief - were correct; for such political action skews public life in ways that hinder rather than facilitate this inquiry, and inevitably and unfairly coerces some to support actions whose rationales are incompatible with deep elements of their worldviews. Rather, political society must recognize that its proper actions cannot be based on any particular outcome of this morally mandatory inquiry, since the correctness of any such outcome is for individuals, families, and voluntary associations, not political societies, to determine. ${ }^{39}$

38. Dignitatis Humanae, 1.

39. Boyle, "The Place of Religion," 22 (emphases added). 
Boyle here uses the notion of coercion a good deal more expansively than Dignitatis Humanae, since he includes governmental actions whose intentions are not to coerce anyone but to favor some, so that any coercive effect is a side-effect. But, as a matter of political philosophy or natural law or human rights, may it not be true that (as Boyle seems to be saying) the immunity of religious acts from coercion extends to policies, especially governmental policies which, albeit as a side-effect, have a coercive impact on those who do or might do religious acts? And may it not also be true that the state's favor for one religion over others, or over irreligion, might entail that the state was making religious judgments, something outside its proper sphere and responsibility? As the prospectus for these lectures ${ }^{40}$ puts it, seeming to take a view like Boyle's: "the principled respect for the autonomy of the individual person expresses itself in the form of principled neutrality on the competing claims of diverse religious communities."

A reflection in response to Boyle and to the lecture prospectus might begin with the Equality Act 2006, s. 52(4)(g), which exempts from that United Kingdom statute's prohibition of discrimination on grounds of religious belief (or unbelief) the following class of decisions by public authorities:

(g) a decision in connection with an application for entry clearance or for leave to enter or remain in the United Kingdom or anything done for the purposes of or in pursuance of a decision of that kind ... if the decision is taken on the grounds-

(i) that a person holds an office or position in connection with a religion or belief or provides services in connection with a religion or belief,

(ii) that a religion or belief is not to be treated in the same way as certain other religions or beliefs, or

(iii) that the exclusion from the United Kingdom of a person to whom paragraph (i) applies is conducive to the public good ...

Though this authorization of discrimination between religions in immigration decisions is narrow, not to say timid, if it is to be understood as covering only a religion's functionaries, rather than any or all of its other non-national members, the provision nonetheless gives us one way of testing Boyle's thesis.

Suppose a general decision is taken by the British authorities that the functionaries of a certain religion are to be excluded on the ground that that religion "is not to be treated"-regarded, assessed, and acted upon-in the same way as most or all other religions precisely because its functionaries teach, or incline its adherents to believe, (say) (i) that any who speak adversely

40. This paper was delivered as a Cardinal Newman Lecture on 15 September 2006, at the Institute for Psychological Sciences, Washington DC. 
of its prophet or decline specific invitations to convert may appropriately be intimidated, assaulted or killed, or (ii) that the British state and its institutions should be subordinated to this religion's laws authorizing coercion of religious acts, polygamy and other violations of British constitutional law and what the British authorities regard as natural law and human rights. Such a general decision, even though restricted to the immigration or expulsion of such functionaries, would be a governmental decision precisely about the content of a religion (at least in the form in which it is ascertainably held by those functionaries and their followers). It would reasonably be taken by everyone to presuppose the judgment that the religion (as so held and professed) is false at least pro tanto. It would in both those ways skew public life against that religion, and would begin to put pressure on its adherents or potential adherents, pressure of a kind that Boyle's line of argument seems to treat as coercion by side-effect if not by intent. Yet it might well, I suggest, be an entirely reasonable decision properly and perhaps urgently required by what the Act calls "the public good" and what Dignitatis Humanae and the European Convention call public order, notably the rights of others and public peace.

For it is a very grave degradation of public order and the temporal common good that there has recently been imported into our polities religious intimidation, extending perceptibly into the operations of the media, the academy, the writing of lectures such as this, and many other institutions of national life. The exclusion or expulsion of those non-nationals who give open or covert or tacit support to the religious doctrines and practices of intimidation is in principle compatible, I suggest, with the true right to religious liberty.

So I do not think that England's highest court must be said to have erred in Shabina Begum's Case this year when, interpreting the European Convention on Human Rights, it dismissed the claim that a state school violated religious liberty when it banned its pupils from attending school clad not in any of the school's prescribed choice of Western- or Muslim-style alternative school uniforms but in a more austere garment of the kind demanded by more militant forms of Islam. The Law Lords used as the decisive premise in most of their judgments the factual and legal findings of the Constitutional Court of Turkey, adopted also by the European Court of Human Rights, ${ }^{41}$ that (1) where Islam (as distinct from other religions) is socially influential even the option of wearing to school or university a distinctively Muslim form of attire is regularly and predictably the occasion and opportunity for intimidatory

41. Şahin v. Turkey (2004) 41 E.H.R.R. 109; see R (Begum) v. Headteacher \& Governors of Denbigh High School [2006] U.K.H.L. 15 at paras. 32 (Lord Bingham), 59-65 (Lord Hoffmann), 91 (Lord Scott), 98 (Baroness Hale). 
pressures, and (2) state governments and laws and other public institutions are accordingly entitled to exclude and forbid that sartorial exercise of religious liberty, in order to preserve public order including the religious liberty of others (and even, sometimes-perhaps often-of the would-be wearer herself) ${ }^{42}$ The Lords' decision implicitly accepts the premise that one religion may and should be treated-understood and dealt with-differently from others (just insofar as its beliefs and practices, perhaps even core beliefs and practices, adversely affect public order, public morality, or the rights of others).$^{43}$ And the Lords' decision should remind us that the right to be free from coercion in one's religious beliefs and acts is a right that is good not only against the state and its government and laws, but also against all other individuals and social groups. If a religion treats coercion of its own adherents, of potential adherents, or of anyone else as permissible, let alone mandatory, it is a standing incitement to violate the rights of others and public order, and those who adhere to it faithfully are rightly liable, in principle, to be kept or, where morally possible, removed as far as is necessary from political communities that acknowledge the right to religious freedom.

\section{VIII}

Joseph Boyle might respond, however, that I have mistaken the focus and exaggerated the reach of his concern that unintended social pressure may impact as coercion impacts on the authenticity and worth of religious behaviour chosen under such pressure. His concern, he might respond, was not with governmental attempts to defend public order from real religious threats. Even though such legitimate defenses of public order may presuppose the falsity of a part of the creed of a particular religion, they need not intend to teach or proclaim that falsity, or anything about the truth or otherwise of that religion or any other religion. Boyle's concern, he might say, was rather with constitutional or governmental declarations intended to identify the correct answer to the question whether there is a true religion. Such declarations cannot plausibly claim to be made for the sake of public order, and (Boyle might say) not only overreach the due limits of the jurisdiction of state government and law, but also create a social pressure prejudicial to the authenticity of religious inquiry and faith. So, he might conclude (and does

42. $R$ (Begum) v Headteacher \& Governors of Denbigh High School [2006] U.K.H.L. 15.

43. Only if and to the extent that it is compatible with this rightful discrimination between religions should one accept the assertion of Jürgen Habermas, Between Naturalism and Religion (Cambridge: Polity Press, 2006), chap. 6 text at n. 20, that "The principle of separation of church and state demands that the institutions of the state operate with strict impartiality vis-àvis religious communities." 
already, I think, imply), there can be no positive duty of state government and law towards the true religion as true (but only the general negative duty owed to all religious communities respectful of the just limits of public order, the duty not to coerce their religious beliefs or practices ${ }^{44}$ ).

Inquiring whether a state's law and government can justly adopt a religion as true does not seem of urgent practical importance. But, urgency aside, it will clarify our political-theoretical reflections to keep that question before us, like a distant peak, and approach it via the foothills.

First, then, the main strands of my reflections entail that the state's government and law cannot justly teach that no religion is true For such a teaching would be false, and false on a matter closely affecting a basic aspect of human wellbeing. And if a state does not teach that but its arrangements give rise, as a side-effect, to widespread belief that the state's government has adopted them because it holds that no religion is true, the government has a significant duty to do what it reasonably can rebut that inference. This it can do most readily by following, in ways that are for it to determine, the Council's injunction to "recognize and favour religion." It is hard to see how government might otherwise counteract the damaging side-effect and false inference than by measures which carry a countervailing implicit message that some religion may well be essentially true and that if so the others, for all their errors, at least have the benefit of mediating the important truth that there is a transcendent source of being, intelligibility and value.

The U.S. Constitution's prohibition of "establishment of religion," as that is interpreted, gives rise to problems hereabouts, which I need not dwell upon. British and other European constitutional arrangements which contain no such provision confront a different problem hereabouts. They can favor religion to the extent needed in justice-namely, by implying if not asserting that some religion may well be true-and can do so by requiring or permitting the teaching and profession of religious faith in state-run or state-funded schools (with suitable opt-outs to preserve religious liberty). But the threat that some religious beliefs present to public order (essentially by authorizing or inciting intimidation), and present in the longer term to the constitutional order which enforces the right to religious liberty, may be such that it is necessary to explicitly withhold from those beliefs the advantages that parity with other religions, combined with weight of numbers, would otherwise require. Such discrimination, though justified, runs so strongly against widespread assump-

44. Here as earlier I leave aside the issue much debated in U.S. constitutional doctrine whether religious acts are presumptively immune ("exempt") from the operation of legal commands or prohibitions of general applicability to religious and non-religious acts alike (i.e. "neutral" as between religiously motivated acts and acts not so motivated). 
tions about "equal protection of the laws" that governments will be sorely tempted to withdraw their favor from all religions, rather than make "invidious comparisons and choices." Yielding to the temptation would create, even if only as a side-effect, the very bad consequence of seeming to express the belief that no religion is true. To incur that consequence deliberately is presumptively unjust. So the discrimination should presumptively be made, with all due care for accuracy and procedural fairness.

Secondly, however we should answer the peak question (about what if anything may be stipulated constitutionally and legally about the true religion), there is certainly an obligation not to hold out as true any religion that is not essentially the true one.

Thirdly, there is a duty not to make subscription to a particular religion, or to one of the many religions, a prerequisite for public offices or benefits. For, subject perhaps to some minor exceptions, such an affirmative "religious test" does have coercive effects of the kind that Joseph Boyle points to as tending to negative authenticity, and does exceed the state's proper bounds. Only when the upholding of public order requires it can it be right to accept those bad side-effects of imposing a negative test such that membership of a religious group threatening to public order becomes a disqualification for public office.

Fourthly, there is a duty not to seek to direct the true religion by claiming a power to appoint its functionaries (say, bishops) or to give or withhold ratification of its doctrinal pronouncements or ecclesiastical arrangements.

Fifthly, however we should answer the peak question, it must be accepted that individual voters and legislators can rightly and should take into account the firm moral teachings of a religion if it is the true religion, so far as its teachings are relevant to issues of law and government. This duty extends only so far as the teachings do not depend upon premises which are essentially questions of present fact and prediction of consequences, for on such questions religious authorities cannot reasonably be supposed to have any special competence, or authority to teach with any decisive effect. In saying that voters and other bearers of public authority have this liberty and responsibility, I assume that the true religion itself holds out its moral teaching as a matter of public reason, i.e. as accessible and acceptable by a purely philosophical enquiry and only clarified and/or made more certain by divine revelation or the theological-doctrinal appropriation of that revelation. And I assume that this holding out is no mere lip-service or idle boast, but goes along with real willingness to shoulder the argumentative burden of making its moral and political teaching philosophically plausible, and maintaining the educational and scholarly resources for doing so. 
Sixthly, then, I think we can give at least this response to the peak question: with the third duty firmly acknowledged as excluding positive religious tests for voting or other public office, and with the negative duties to abstain from coercion all firmly in place, it does not seem to be contrary either to what experience shows are the exigencies of authenticity in religious enquiry, or to what seem likely to be the conclusions of revelation as well as philosophy about limits to the state's coercive jurisdiction and temporal authority, to hold that in establishing their constitutional arrangements a people might without injustice or political impropriety record solemnly their belief about the identity and name of the true religious faith and community.

Even when politically possible, making such a declaration might in many circumstances have such bad side-effects that doing so would be unfair or otherwise unreasonable. And it would always be a quite unfitting declaration to make if the adherents of the religion so identified did not accept and act on the responsibility which I mentioned earlier, of showing how their faith embraces and is continuous with public philosophical, historical and moral reason. 